\title{
A Travessia AtLÂnTICA COMO UM Trajeto INICIÁtICO NOS ROMANCES DE FORMAÇÃO UN OCÉAN, DEUX MERS, TROIS CONTINENTS, DE WILFRID N'SONDÉ, E A RAINHA GINGA, DE JOSÉ EDUARDo AGUALUSA
}

Andreia J.O. Silva ${ }^{1}$

\begin{abstract}
Resumo: O objetivo deste artigo é refletir sobre a travessia atlântica no eixo Sul-Sul e o seu caráter iniciático nos romances de formação (Bildungsroman) Un océan, deux mers, trois continents, de Wilfried N'Sondé e A Rainha Ginga de José Eduardo Agualusa. Na leitura comparatista proposta, salientaremos a complementaridade dos romances estudados que narram um contexto histórico específico: o comércio transatlântico de escravos durante os séc. XVI e XVII. Debruçar-nos-emos mais especificamente sobre a questão da travessia atlântica e todos os aspetos inerentes à viagem: separação da terra natal, solidão, questionamento e reflexão pessoais. Elementos que ao longo de ambas as obras conduzirão os protagonistas a uma morte iniciática e a uma posterior ressurreição simbólica, culminando num processo de construção identitária, consciência humanista e descrença religiosa.
\end{abstract}

PALAVRAS-CHAVE: Travessia atlântica; Bildungsroman; iniciação; ritos iniciáticos.

\section{The Atlantic Crossing as an Initiatory Path on the Novels of Formation Un OcÉan, DeUX

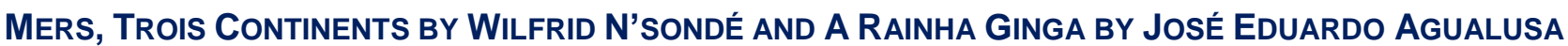

ABSTRACT: The aim of this article is to reflect on the Atlantic crossing in the south-south axis and its initiatory character in the novels of formation (Bildungsroman) Un océan, deux mers, trois continents, by Wilfried N'Sondé and $A$ Rainha Ginga by José Eduardo Agualusa. In the comparative study proposed, we will emphasize the complementarity of the novels studied that narrate a specific historical context: the transatlantic slave trade during the 16th and 17th centuries. We will look more specifically at the Atlantic crossing and all the aspects of the journey: separation of the homeland, solitude, questioning and personal reflection. These elements lead the protagonists to an initiatory death and a later symbolic resurrection, culminating in a process of identity building, humanistic consciousness and religious disbelief.

KEYwORDS: Atlantic crossing; Bildungsroman; initiation; initiatory rites.

Neste artigo propomos uma leitura comparatista das obras Un océan, deux mers, trois continents de Wilfriend N'Sondé, e A Rainha Ginga, de José Eduardo Agualusa. A nossa análise incidirá sobre a concepção do Atlântico como um espaço de aprendizagem, a travessia atlântica no eixo Sul-Sul e o seu caráter iniciático nos dois romances de formação.

1 Doutoranda em Literatura Comparada (regime de cotutela internacional) na Universidade Jean Monnet, França, e na Universidade do Porto, Portugal. E-mail: andreiajsilva@live.com. 


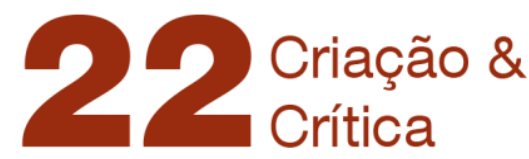

Este artigo encontra-se dividido em três partes: na primeira parte, propomos a introdução das obras citadas no gênero literário romance de formação (Bildungsroman) e refletimos sobre a pertinência da interpretação do Atlântico como um espaço de aprendizagem. Na segunda parte, relacionamos a travessia atlântica com os ritos de iniciaçãoancestrais. Demonstramos neste ponto em que medida alguns elementos da viagem irão proporcionar uma morte iniciática levando posteriormente a uma ressurreição simbólica.

Por último, na terceira parte, vemos de que forma essa ressurreição simbólica irá conduzir a uma progressiva descrença na fé católica, por parte dos protagonistas (ambos padres da Igreja Católica), permitindo um processo de reconstrução identitária e a concepção de um novo ideal de humanidade desprovido de dogmas religiosos.

As duas obras aqui estudadas são contemporâneas: a primeira que referimos foi publicada em janeiro de 2018 e a segunda em junho de 2014. As narrações decorrem nos sécs. XVI e XVII, em pleno contexto histórico da "descoberta" ${ }^{2}$ do Novo Mundo, do comércio triangular África-América-Europa e do tráfico transatlântico de escravos.

Em Un océan, deux mers, trois continents, Wilfriend N'Sondé, escritor congolês, dá-nos a conhecer o trajeto que Nsaku Ne Vunda, batizado Dom António Manuel, percorre desde a sua terra natal até ao Vaticano. Este jovem padre, personagem histórico e cuja viagem narrada é verídica, nasceu em 1583 nas margens do rio Kongo. Órfão, criado no respeito pelos antepassados e educado pelos missionários, será embaixador do rei dos Bakongos, Mvemba Nzinga, batizado Afonso I do Congo, junto do papa. No momento da partida, o padre ignora que a sua viagem até Roma passará pelo Brasil e que a mesma será feita a bordo de um navio negreiro. Nsaku Ne Vunda atravessará o Atlântico a bordo deste navio descrevendo os horrores que vê, ouve e sente. Questionando o mundo, os homens e Deus. Ao longo da sua viagem, que durou três anos, Dom António Manuel atravessa o Oceano Atlântico do Reino do Congo ${ }^{3}$ até ao Brasil; do Brasil até Lisboa; e de Lisboa vai até Madrid (esta última viagem é realizada a pé, na qual ele enfrentará os interrogatórios sumários da Santa Inquisição e a prisão em Toledo). De Madrid partirá para Roma, de barco, atravessando o Mar Mediterrâneo e chegando assim a Roma no dia 3 de janeiro de 1608, doente, fraco, e morrendo três dias depois aos pés do papa Paulo V.

No segundo romance que analisaremos neste artigo, José Eduardo Agualusa narra a história da personagem histórica Nzinga Mbande Cakombe, rainha Ginga ${ }^{4}$, através de Francisco José da Santa Cruz, padre jesuíta pernambucano que chega a Salvador do Congo em 1620 a bordo de um navio negreiro para se juntar aos restantes padres jesuítas que tinham aí fundado uma escola. Alguns meses depois da sua chegada

\footnotetext{
2 Colocaremos o termo "descoberta" entre aspas devido às problemáticas que o seu uso levanta e aos debates que tem suscitado na área dos estudos pós-coloniais.

3 O Reino do Congo, ou Império do Congo, fundado no séc. XIII, era um território africano, situado no sudoeste africano e cujo território hoje corresponde a uma parte de Angola, a Cabinda, à República do Congo e a uma parte da República Democrática Do Congo e do Gabão.

4 Encontraremos o seu nome escrito de diversas formas, consoante as obras, os autores ou ainda as línguas nas quais estas obras foram publicadas. Alguns exemplos: Ngola (rainha) Nzinga, Rainha N'Ginga, Rainha Ginga, Rainha Nzinga, Ana Nzinga, entre outros.
} 


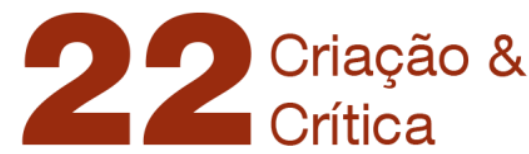

torna-se secretário e conselheiro da rainha Ginga, irmã do rei do Dongo. A narração, construída em analepse, conta-nos uma parte da vasta História de Angola e a História desta rainha que resistiu aos portugueses, lutando contra eles. Toda a história é narrada por Francisco José que põe Ginga em evidência e apresenta-nos com precisão histórica este personagem de relevo assim como o território sobre o qual reinou. Nesta narrativa, Francisco José dá-nos conta das várias travessias que efetuou em torno do espaço que nos propomos abordar: o atlântico é cruzado no sentido África-Brasil e Brasil-África, pelo narrador, formando-se, através desse próprio processo de travessias, um personagem híbrido a nível cultural e identitário.

As duas obras estudadas são romances históricos: gênero literário que, de acordo com Lukács, surge no início do séc. XIX, em plena revolução industrial. O pano de fundo para o romance histórico é um período histórico (ou episódio) específico no qual se movem personagens reais ou fictícias. Trata-se de um romance que está ligado a uma época histórica específica: neste caso, os dois romances abordam a questão do tráfico negreiro transatlântico nos séc. XVI e XVII.

Os personagens que iremos encontrar ao longo das obras derivam da especificidade histórica do tempo narrado e irão viver um processo de transformação (Bildung) proporcionado por este contexto histórico específico, tal como veremos a seguir.

\section{O Bildungsroman e o Atlântico como um espaço de aprendizagem}

Antes de prosseguirmos com a inclusão das obras citadas no gênero literário romance de formação ou Bildungsroman, cabe-nos aqui inserir uma nota introdutória sobre o Atlântico e a concepção deste espaço nos estudos literários. Segundo Moura e Porra (2015), o espaço atlântico torna-se um lugar privilegiado de expansão das culturas e literaturas de línguas europeias ao longo do séc. XX e mais concretamente após a Segunda Guerra Mundial. As línguas faladas nos territórios em torno do Oceano Atlântico (inglês, francês, português, espanhol e neerlandês) permitem uma série de dinâmicas e trocas culturais e literárias num espaço carregado de uma história de poder e dominação:

Se o colonialismo, sem dúvida alguma, legou uma história comum aos dois lados do Atlântico, é conveniente observar em que medida esta é interpretada e escrita pelos escritores contemporâneos pertencentes a este espaço intermédio. ${ }^{5}$ (POTEVIN, 2012, p. 85, tradução nossa)

Nos seus trabalhos relativos aos estudos transatlânticos, Jean-Marc Moura considera que para além do fenômeno de moda em torno da noção de mundo atlântico, o número considerável de publicações associadas a este termo remete-nos para "[...] um

5 No original: "Si le colonialisme a sans aucun doute légué une histoire commune aux deux côtés de l'Atlantique, il convient de voir dans quelle mesure celle-ci est interprétée et écrite par des écrivains contemporains appartenant à cet espace de l'entre-deux". 


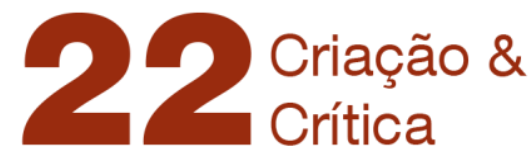

espaço concebido como um conjunto íntegro, unitário entre três continentes. "' (MOURA, 2012, p.11, tradução nossa).

Nestas obras, este espaço de circulação, trocas e migrações é também apreendido como um espaço de passagem para uma outra existência e, por conseguinte, um espaço de aprendizagem, de amadurecimento e de autoformação.

Como vimos acima, existe uma série de paralelismos que nos levam a analisar estas obras através de uma perspectiva comparatista. Não só os dois romances narram o mesmo período histórico tecendo considerações e reflexões de cunho humanista ${ }^{7}$, como ambos os protagonistas, formados pela Igreja Católica para serem padres, e atravessando o Atlântico a bordo de navio negreiro, irão experienciar uma trajetória de aventuras e sofrimento levando a uma aprendizagem e amadurecimento, a Bildung ${ }^{8}$, que nos permite classificar estes romances como Bildungsromans (também denominados como romance de formação, romance de aprendizagem ${ }^{9}$, entre outros).

A designação de Bildungroman surge em 1810 por Karl von Morgenstern e a sua classificação como sugênero de romance é ainda questionada e problematizada. $\mathrm{O}$ romance modelo do Bildungsroman é a obra Os anos de aprendizagem de Wilhelm Meister de Goethe, publicado em 1795, na Alemanha. De acordo com Puga, podemos definir o romance de formação como

uma narrativa ficcional que representa o percurso de formação de uma criança ou adolescente/jovem até à fase adulta da sua vida, bem como todos os obstáculos e provas que ultrapassa, sendo o processo formativo predominantemente informal, por relativa oposição à educação formal ou escolar. (PUGA, 2016, p. 10)

No Bildungsroman, a questão primordial não é tanto o crescimento ou a evolução física do personagem, mas sim o seu amadurecimento: o personagem vai passando por várias etapas e provas que vão potencializar a sua formação enquanto indivíduo. É de salientar que, muitas vezes, estas provas assumem um carácter dramático, violento, de perda, de imposição e de manipulação. Esta formação é lenta e assume a sua forma no final do romance, podendo este ficar em aberto ou não. Neste tipo de romance, é assumida a formação tanto do protagonista como do leitor nos princípios do humanismo (QUINTALE NETO, 2005).

Neste gênero (ou subgênero, como alguns estudiosos o classificam), a narração apresenta-nos a partida do jovem da terra natal, após um período de inocência e de vivência no seio familiar. Sem conhecimento do mundo nem das leis dos homens,

6 No original: "[...] un espace conçu comme ensemble intègre, unitaire, entre trois continentes".

7 Iremos apoiar-nos no significado de humanismo da corrente filosófica e racionalista cuja visão do mundo e idealizações estão centradas no Homem.

8 "Designating alternatively physical beauty, intellectual cultivation, the divin imprint on the human mind, the integration of the individual into society, and the constantly emphasized parallelism between Greek culture and German culture, the term Bildung is certainly one of those words whose translation seems the most aleatory." (RENDALL e AL., 2014) Palavra intraduzível, cuja raiz Bild se refere a imagem, a imagem que se forma. Geralmente este termo é interpretado como formação e construção do indivíduo enquanto ser físico e espiritual.

9 Em francês o termo "roman d'apprentissage" é também empregue. 


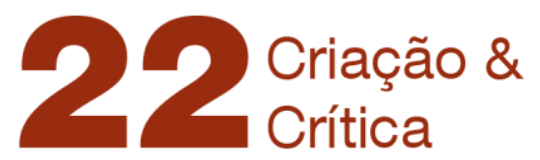

"conhecia do mundo apenas o que lera nos livros e, de súbito achava-me ali, naquela África remota, cercado pela cobiça e pela infinita crueldade dos homens (AGUALUSA, 2014, p. 25)".

Momentos antes da partida, deixaram que o meu pai adotivo, chegando em passo apressado, me abraçasse. Sussurrou-me aos ouvidos agradecimentos, orgulhoso de mim por ter desviado, por magia, os militares da sua missão primeira, salvando a aldeia e os seus habitantes ${ }^{10}$. (N'SONDÉ, 2018, p. 35, tradução nossa)

Após a partida e o abandono da casa paterna e da terra natal, movido por um desejo individual ou por um motivo de força maior, o herói passará por uma série de provas e obstáculos que poderão ser assemelhados aos ritos de passagem ou ritos iniciáticos, tal como recorda Puga (2016):

Os sucessivos encontros e conflitos ao longo da viagem funcionam como ritos de passagem/iniciação para os jovens, cujos conhecimentos e personalidades se desenvolvem como nunca, estabelecendo-se assim um corte com o passado. (PUGA, 2016, p. 32)

Estes obstáculos serão de várias ordens e poderão ser representados pela dor, pela perda, pelo isolamento, pela violência vivida ou sentida. Mais à frente, abordaremos este aspeto em detalhe, fazendo um contraponto com os ritos de iniciação ancestrais, a morte e o seu caráter formativo, bem como a passagem dos jovens à idade adulta por meio de determinados rituais.

Uma outra problemática inerente ao Bildungsroman é o conflito entre o individual e o coletivo. O jovem, que passa da esfera privada e do seio familiar à descoberta do mundo, descobre também o coletivo. Esta descoberta pode ser consciente ou inconsciente, livre ou forçada, o herói pode não se aperceber que passa de uma esfera à outra, mas é a preocupação com o coletivo, com a comunidade à qual o protagonista pertence, que reflete um amadurecimento intelectual e um processo de identificação com o Outro.

$\mathrm{Na}$ obra de N'Sondé, o protagonista, ao tomar conhecimento que será o embaixador do rei do Kongo junto do papa, passa por vários estados: medo por ter sido chamado junto do rei subitamente; euforia por poder embarcar para a Europa (considerada como a terra santa e católica por excelência) e ir para o Vaticano incumbido de uma tão importante missão; tormento e dúvidas relativamente aos verdadeiros motivos que o levaram a ser escolhido para esta missão.

Em direção ao porto de Luanda, Nsuka Ne Vunda, Dom António Manuel de batismo, presencia pela primeira vez um grupo de escravos, agrilhoados e caminhando em fila, vendo-os depois, os mesmos ou outros, junto do forte que reunia os escravos

10 No original: "Juste avant le départ, on permit à mon père adoptif, réapparu au pas de course, de m'embrasser. Celui-ci me susurra des remerciements à l'oreille, fier qu'il était de moi qui avais détourné, par magie, les militaires de leur mission initiale, sauvé le village et surtout ses habitants." 
para depois os embarcar. O odor nauseabundo de carne queimada pelo ferro em brasa, assim como os gritos atrozes, levam o herói a redobrar as suas forças e a incumbir-se do seu espírito de missão para agir em prol do coletivo

Mesmo tendo baixado a cabeça e desviado o olhar, os meus pensamentos foram sinceros e profundos em relações àqueles infelizes, começava a compreender a importância da minha missão e murmurava rezas pela salvação daquelas almas: que não se resignassem nunca ao estatuto de animais de carga aos quais os queriam reduzir, que tivessem sobretudo a força de guardar o orgulho, sem perder nem o gosto pela liberdade nem a crença que chegaria o dia em que eles alcançariam a terra aprazível e eterna junto de nosso Senhor. No meu íntimo desvaneceram-se as preocupações, a minha tarefa continuava vasta e, no entanto, a necessidade e a urgência de pôr um fim ao negócio de desumanização dos meus deram-me coragem para seguir em frente. ${ }^{11}$ (N'SONDÉ, 2018, p. 57 , tradução nossa)

No entanto, o protagonista sofre um choque violento ao chegar ao porto: no navio, toma conhecimento que a sua viagem durará vários meses e que passará pelo Brasil antes de ir para a Europa. Este choque leva-o a distanciar-se do coletivo, a fechar-se em si mesmo maldizendo a sua sorte e sonhando em voltar à terra natal. Este distanciamento leva Nsaku Ne Vunda a fechar-se no compartimento que lhe reservaram a bordo do Le Vent Paraclet, a recusar as refeições e qualquer contato com os restantes membros da equipagem do navio. Assistimos aqui a um conflito entre o indivíduo e o mundo em formação. O mundo narrado é de tal forma atroz e violento que a única hipótese de sobrevivência e de resistência psicológica é o distanciamento.

Em A Rainha Ginga, Francisco José, filho de uma mãe índia da nação Caeté e de um pai mulato, ele mesmo filho de um comerciante da Póvoa do Varzim e de uma negra, apesar de "[ser] a soma, por certo um tanto extravagante, de todos esses sangues inimigos" (AGUALUSA, 2014, p. 15), é enviado para a África a serviço dos portugueses. Porém, cedo se colocará do lado de Ginga, defendendo o coletivo africano, mesmo sentindo-se e sendo acusado de traidor pelo coletivo português. O padre pernambucano, em detrimento da sua posição no seio da Igreja, ao longo da narrativa, vai despojando-se do individual para se afirmar por um todo, estrangeiro a si, mas cujos princípios e razões defende como sendo seus.

Se em ambos os romances estamos perante condições históricas que possibilitam a Bildung dos protagonistas, é também a descoberta do amor (muito importante neste caso visto que se trata de homens da Igreja) que contribuirá para a

11 No original: "Si je baissai la tête et détournai mon regard, mes pensées furent sincères et profondes envers ces malheureux, je commençai à saisir l'importance de ma mission et murmurai des prières pour le salut de leurs âmes: qu'ils ne se résignent jamais au statut de bêtes de somme auquel on voulait les réduire, surtout qu'ils aient la force de conserver leur fierté et ne perdent ni le goût de la liberté ni la croyance qu'un jour viendrait où ils atteindraient les contrées paisibles et éternelles auprès de notre Seigneur. En mon for intérieur s'estompèrent les inquiétudes, ma tâche restait immense mais la nécessité et l'urgence de mettre un terme à l'entreprise de déshumanisation des miens me donnèrent de l'allant". 


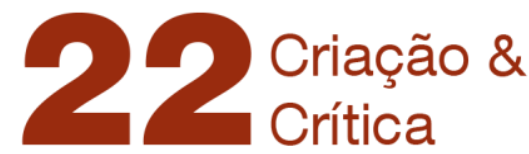

formação e a realização pessoal de ambos. Esta descoberta assume um cunho simbólico uma vez que é potencializada pelos mentores, figura primordial neste subgênero: "O agente da Bildung no romance de formação é geralmente o mundo social circundante, usufruindo os protagonistas das lições desse ambiente e de guides figures (paternais e maternais) para iniciar a sua vida adulta (PUGA, 2016, p. 15)".

Se atentarmos na figura dos mentores, podemos afirmar que, nos dois romances em análise, os protagonistas encontram figuras masculinas que assumem um papel de intermediário/mediador, auxiliador ou ainda mensageiro, mas são as personagens femininas que assumem o papel de mentor. O mentor, ao contrário do auxiliador, devido à sua sabedoria e grandeza de espírito, não só apoia, mas inspira e impulsiona o herói no seu percurso.

Em Un océan, deux mers, trois continents, é Thérèse (que se disfarça inicialmente sob a identidade de Martin) que vai potencializar o processo de descobrimento e de formação do nosso protagonista. No momento da sua chegada ao navio Le Vent Paraclet, Dom António Manuel depara-se com um ambiente hostil. Sente, de antemão, que as relações com o resto da equipagem serão difíceis, pois veem nele um semelhante aos que se encontram no porão. Não entendem como pode o capitão do navio receber um negro a bordo e tratá-lo com regalias.

Martin, um jovem aprendiz de marinheiro, surge para Dom António como uma figura sensível e espiritual naquele inferno de horrores. É Martin que explica a Dom António o que fazer, como se comportar e o elucida sobre o desenrolar do resto da viagem. O primeiro contato demonstra de imediato uma relação de teor espiritual: "A luz daquele olhar sondou-me num instante, enviou-me para uma outra dimensão, um parêntesis no qual comunicamos sem trocar uma palavra"12 (N'SONDÉ, 2018, p. 73, tradução nossa).

Os dias passam no navio e o único refúgio de Dom António é a presença de Martin. Ambos se apoiam entre si e a existência do outro ajuda a suportar as atrocidades presenciadas a bordo. Tornam-se companheiros inseparáveis. É num momento de desespero e de dor que Martin se confia a Dom António, fazendo com que os laços que os unem sejam mais fortes. Há uma comunhão universal entre os dois, um amor etéreo, que os leva a suportar aquela existência. "A confiança que ele tinha em mim, reconciliavame com a minha vontade de fazer o bem aos outros e de me compadecer"13 (N'SONDÉ, 2018 , p. 93, tradução nossa); "Felizmente, Martin estava ali. Desejava que ele ficasse junto a mim, acontecesse o que acontecesse. Ele tinha-se tornado a minha bússola, o meu farol na tempestade, o meu único amigo"14 (N'SONDÉ, 2018, p. 124, tradução nossa).

12 No original: "La lumière de ce regard-là me sonda en un instant, me précipita dans une autre dimension, une parenthèse dans laquelle nous communiquions dans dire un mot".

13 No original: "La confiance qu'il m'accordait me réconciliait avec ma volonté de faire le bien des autres et de compatir",

14 No original: "Heureusement, il y avait Martin. Je souhaitais qu'il reste auprès de moi, quoi qu'il arrive. II était devenu mon repère, mon phare dans la tourmente, mon seul ami". 


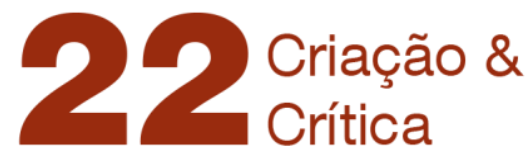

No entanto, Martin revela ser uma moça, Thérèse, que tinha escapado à fome e à miséria disfarçando-se de homem e embarcando para o Novo Mundo. É neste momento que a relação entre ambos se estreita ainda mais.

A confiança partilhada ligava-nos ainda mais, ela selava uma nova aliança, tivemos desde então um objetivo comum e decidimos protegermo-nos um ao outro. Graças ao nosso acordo, resistiríamos sem o conhecimento daqueles que nos rodeavam, éramos dois. ${ }^{15}$ (N'SONDÉ, 2018, p. 153, tradução nossa)

A partir desse momento, ainda mais confiantes e compassivos, arriscaríamos a nossa vida juntos, eu assumiria o seu fardo, ela suportaria o peso que eu carregava nos meus ombros. ${ }^{16}$ (N'SONDÉ, 2018, p. 156, tradução nossa)

Dotado de um sentimento de proteção e incumbido de uma missão quase ancestral de respeito e cuidado do sexo feminino, Nsaku Ne Vunda redobra os cuidados com Thérèse e aproxima-se cada vez mais dela.

É ela, cumprindo o seu papel de mentora, que o irá guiar, apoiar ao longo da sua missão e que o irá salvar no momento da sua prisão pela Santa Inquisição. Ao fazer sua a missão de Dom António, ela está não só a dar um sentido imediato à sua existência como a impulsionar o protagonista na sua missão derradeira.

Em A Rainha Ginga, existem duas mulheres que desempenham papéis diferentes na formação do protagonista. Por um lado, Ginga, que representa a mulher estratega, astuta, viril, altiva e eloquente. É através dela que ele sente que a presença portuguesa em Angola é uma causa inútil e sem sentido. Ao colocar-se progressivamente do lado de Ginga, vai defendendo os seus fundamentos e os da sua corte, vai sendo transformado por uma mulher que, de um certo modo, teme tanto quanto admira. O padre Jerónimo Vogado, numa visita a Luanda e sentindo a intimidade de Francisco José com Ginga, citaIhe um provérbio ambundo ilustrativo "Por muito tempo que um tronco permaneça no rio nunca se transformará num crocodilo" (AGUALUSA, 2014, p. 61).

Por outro lado, Muxima, que representa o exotismo da mulher africana, doce, inocente enquanto jovem, e após o batismo tornando-se Dona Inês de Mendonça, arrogante, forte e autoritária. É através dela que Francisco José descobre o amor no qual sente não haver pecado algum, apesar de ainda ser um homem da lgreja.

Recebíamos a ajuda das mulheres, entre as quais Muxima, sempre atenta e caridosa. Cuidando dos feridos, uma ou outra ocasião os dedos dela tocavam os meus, e então esquecia-me da bruteza dos homens e da

\footnotetext{
15 No original: "La confiance partagée nous lia encore plus, elle scella une alliance nouvelle, nous eûmes dès lors un objectif commun et décidâmes de nous protéger l'un l'autre. Forts de notre accord, nous résisterions de concert à l'insu de notre entourage, nous étions deux".

16 No original: "À partir de ce moment-là, encore plus confiants et bienveillants, nous risquerions notre vie ensemble, je prendrais son fardeau, elle supporterait le poids qui pesait sur mes épaules".
} 


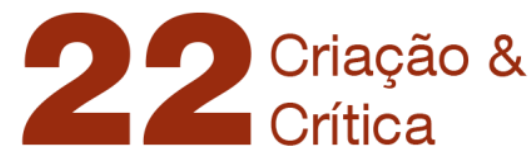

angústia daqueles dias e era como se o mundo se estivesse formando de novo, sem erro nem pecado algum. (AGUALUSA, 2014, p. 65)

Este excerto, que se passa durante o cerco que os portugueses fazem ao quilombo da rainha Ginga, descreve não só as atrocidades e os horrores de um tempo de guerra, mas também nos mostra um herói que descobre o mundo e se descobre a si mesmo. A Bildung vai-se operando em Francisco José, dando-lhe a sensação que o (seu) mundo se está formando de novo. Esta mudança de percepção ocorre, não só devido ao obstáculo e à prova pela qual ele está a passar (clausura, guerra, mortes e sofrimento), mas também devido à descoberta do amor e posteriormente da sexualidade, característica do Bildungsroman. Esta nova visão do mundo, do eu, do amor, é vista "sem erro nem pecado algum" e o distanciamento relativamente à Igreja Católica vai-se concretizando progressivamente.

O protagonista, juntamente com a(s) personagem(s) feminina(s), irá partilhar experiências que resultarão num processo de formação paralelo e complementar. "Era como se o mundo se estivesse formando de novo" remete-nos para a transformação que se opera em Francisco José. Não só Muxima vai propiciar esta mudança através do seu amor e dedicação, mas também ela irá sofrer uma Bildung que a levará a uma transformação interna, concretizada mais tarde no seu batismo e na mão de ferro com que irá governar a casa da sua antiga patroa, de quem herdou os negócios.

Também Ginga passará por um momento de aprendizagem, formando-se não só com os conselhos de Francisco José, mas também com todas as guerras e negociações das quais será protagonista.

Um dos elementos fundamentais da Bildung dos personagens é a viagem, e neste caso específico a travessia ou as travessias que são vividas de forma diferente pelos protagonistas dos dois romances. N'Sondé conduz-nos pelo horror do navio negreiro, descrevendo detalhadamente o embarque, as condições de vida a bordo, os gritos e gemidos que se soltam do porão, os cheiros e imundícies a bordo. Tudo isto perante o olhar indiferente da equipagem. A travessia que é efetuada ao longo desta viagem inesperada através do Atlântico (Francisco José acredita que do Kongo iria diretamente a Roma, sem passar pelo Brasil) é não só física, mas também interna, de cunho espiritual. Trata-se de uma travessia tripla: a do protagonista, a dos escravos e a do leitor. Perante as atrocidades vividas, Deus é uma figura ausente-presente.

No romance de Agualusa, o Atlântico Sul é atravessado no sentido África-Brasil e mais tarde na diegese, no sentido Brasil-África. No entanto, estas viagens não são alvo de extensas descrições, tal como acontece em N'Sondé, onde é dada uma grande importância ao relato da viagem. Esta "falta" de descrição da travessia parece-nos ser de grande importância, uma vez que em Agualusa não é a descrição da travessia que é importante, mas sim a transformação que daí advém. Sabemos que a viagem irá transformar o protagonista, mas não nos são dados a conhecer os detalhes da viagem e os estados de espírito pelo qual ele passa. A reflexão e a transformação do herói serão dadas a conhecer ao leitor mais tarde na narração. 


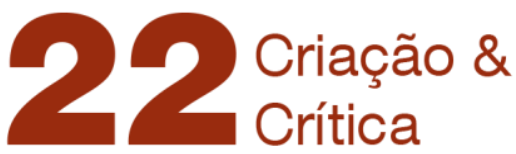

Por outro lado, N'Sondé ao oferecer-nos um relato descritivo da viagem, força o leitor a viver a travessia com os escravos, sentindo o tempo longo da navegação e os martírios sofridos a bordo. A viagem, repleta de dor, sofrimento e questionamento, é propositadamente descrita de forma a acentuar a travessia num plano concreto (a navegação pelo oceano), mas também interna, ou seja, a travessia espiritual e psicológica que Dom António Manuel vai enfrentar, que o fará amadurecer, que o irá formar e que irá aos poucos mudando a sua visão do mundo, de Deus e dos homens.

Estamos aqui perante duas Bildung bem-sucedidas. Por um lado, o padre Francisco José, após a tomada de Luanda aos flamengos pelos portugueses, refugia-se em Amsterdã com o seu filho Cristóvão onde cria uma livraria para comporem "livros belíssimos"; por outro, o padre Nsaku Ne Vunda morre aos pés do papa não sem antes nos descrever com minúcia e detalhe o fausto, a opulência e a arrogância que reina no Vaticano e entre os membros eclesiásticos, demonstrando toda a sua desilusão e desencanto no que diz respeito à Igreja Católica e aos seus representantes.

No entanto, no final da narração, em ambas as obras há uma reconciliação com o mundo e com os homens, uma espécie de perdão universal que alimenta o ideal de uma humanidade livre:

Parti aliviado das minhas desilusões, das traições, do fogo e da loucura dos homens, preparado para realizar o meu sonho de eternidade, convencido que o infinito dos tempos seria suficientemente vasto para dar a cada um pouco de justiça e de dignidade. [...] O meu périplo ensinarame o movimento para a frente, mais enriquecedor do que o recuo na nostalgia do passado. ${ }^{17}$ (N'SONDÉ, 2018, p. 268, tradução nossa)

Não voltei a ver Cipriano, o Mouro. Chegou-me, contudo, uma carta dele [...]. Tratava-me por irmão e afirmava estar sempre comigo: "Assim como as águas de um rio não desaparecem depois que passam por nós, apenas se movem para um outro lugar, assim também os dias não se esgotam nunca - apenas vão para um outro lugar. Continuo a conversar contigo nas horas eternas em que conversámos, e essas são as horas boas da vida". (AGUALUSA, 2014, p. 278)

\section{A travessia e a viagem como ritos de iniciação: da morte iniciática à ressurreição simbólica}

Como já referido antes, este artigo sugere que o Atlântico, nos romances analisados, é vivido como um espaço de formação, de construção de si, de aproximação do Outro e de descoberta de uma identidade. Deste modo, o Oceano Atlântico poderá ser considerado como um espaço iniciático.

17 No original: "Je partis allégé de mes désillusions, des trahisons, du feu et de la folie des hommes, prêt à accomplir mon rêve d'éternité, convaincu que l'infini des temps serait assez vaste pour rendre à chacun son lot de justice et de dignité. [...] Mon périple m'avait enseigné le mouvement vers l'avant, plus enrichissant que le repli dans la nostalgie du passé." 


\title{
$222_{\substack{\text { Criacica \& } \\ \text { crica }}}$
}

Sendo a travessia um trajeto de iniciação, ela irá propiciar aos protagonistas não apenas uma descoberta de si, mas também do sagrado e do profano. Como lembrou Mircea Eliade:

\begin{abstract}
Entende-se geralmente por iniciação um conjunto de ritos e de ensinamentos orais que têm como objetivo a modificação radical do estatuto religioso e social do indivíduo a iniciar. A nível filosófico, a iniciação equivale a uma mutação ontológica do regime existencial. No final das suas provas, o neófito desfruta de existência bem diferente do que antes da iniciação: ele tornou-se num outro. ${ }^{18}$ (ELIADE, 1959, p. 12, tradução nossa)
\end{abstract}

Um dos elementos primordiais nos ritos de iniciação ancestrais (alguns ainda praticados em determinadas comunidades tribais africanas, aborígenes, indígenas, entre outras) é a passagem por uma morte iniciática. Este aspeto vivido de forma mais ou menos violenta consoante os locais e tradições é o elemento-chave que transformará o jovem (ou o noviço, pois ainda não foi iniciado) em homem. Havendo também ritos iniciáticos dedicados ao sexo feminino, abordaremos aqui apenas aqueles que são destinados ao sexo masculino.

A maioria das provas iniciáticas implicam, de uma forma mais ou menos transparente, uma morte ritual seguida de uma resurreição ou de um novo nascimento. O momento central de todas as iniciações é representado pela cerimónia que simboliza a morte do neófito e o seu regresso por entre os vivos. Mas ele regressa à vida como um homem novo, assumindo uma nova forma de ser. A morte iniciática significa o fim da infância, da ignorância e da condição profana. ${ }^{19}$ (ELIADE, 1959, p. 16, tradução nossa)

De acordo com Mircea Eliade (1959), a morte corresponde a um regresso ao caos, representando o fim de uma forma de ser e de agir. Ela permite a formação de um homem novo e de uma nova vida espiritual. Esta morte iniciática é quase sempre representada pelas trevas, pela noite cósmica, pela cabana no meio da floresta, pelo ventre do monstro, etc. Todas estas imagens representam um retorno a um estado préformal, embrionário, que demonstra que um novo ser está prestes a nascer.

$\mathrm{Na}$ obra de Eliade, o noviço torna-se homem porque tem uma revelação do mundo, da existência e do sagrado. Seria normal pensarmos que ambos os protagonistas já viveram os ritos iniciáticos próprios da Igreja Católica como o batismo, a comunhão, a

18 No original: "On comprend généralement par initiation un ensemble de rites et d'enseignements oraux, qui poursuit la modification radicale du statut religieux et social du sujet à initier. Philosophiquement parlant, l'initiation équivaut à une mutation ontologique du régime existentiel. A la fin de ses épreuves, le néophyte jouit d'une tout autre existence qu'avant l'initiation : il est devenu un autre".

19 No original: "La majorité des épreuves initiatiques impliquent, d'une façon plus ou moins transparente, une mort rituelle suivie d'une résurrection ou d'une nouvelle naissance. Le moment central de toute initiation est représenté par la cérémonie qui symbolise la mort du néophyte et son retour parmi les vivants. Mais il revient à la vie un homme nouveau, assumant un autre mode d'être. La mort initiatique signifie la fin de l'enfance, de l'ignorance et de la condition profane". 


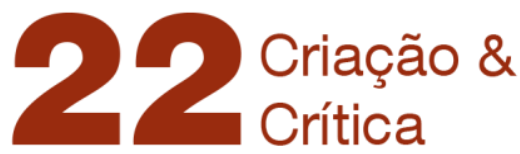

confirmação e a ordenação como padres, e que, por conseguinte, o mundo sagrado já Ihes foi dado a conhecer. No entanto, a viagem e a Bildung que experienciam vai conduzilos ao verdadeiro mundo sagrado, absoluto, universal, representando pela liberdade, pelo conhecimento e pelo amor.

A morte tem um caráter formativo no Bildungsroman. Assiste-se em ambos os romances a dois tipos de morte: a do eu e a dos outros. A do eu é simbólica ao longo da diegese e permite a passagem de um estado a outro. É representada pela clausura e pelo confinamento num espaço fechado (em N'Sondé é o navio - descrito como túmulo e sepulcro em madeira - e mais tarde, a prisão da Inquisição Espanhola; em Agualusa é o quarto da fuga a Ngola, o cerco ao quilombo de Ginga e o engenho pernambucano que lhe serve de prisão durante meses), são as febres seguidas de sonhos e visões que assolam ambos os protagonistas e os deixam num estado límbico, em que não conseguem distinguir se estão vivos ou mortos. Um outro elemento que representa a morte iniciática é, nas duas obras e num dado momento da travessia, a errância marítima: o sentimento de estarem perdidos no vasto oceano Atlântico, com pouca ou nenhuma água, sem comida.

É também a morte dos outros: daqueles que os rodeiam, dos companheiros de viagem, de todos os homens e mulheres feitos escravos e vendidos como mercadoria. Estas mortes contribuirão para o questionamento existencial, para as indagações filosóficas e para as dúvidas religiosas, que levam à transformação do personagem ao longo da narrativa.

Retomando os elementos iniciáticos, reconhecemo-los também juntamente com outras estruturas da experiência religiosa, na vida imaginária e onírica do homem moderno. Mas também os reconhecemos em um certo tipo de provas reais que ele enfrenta, nas crises espirituais, na solidão e no desespero que todo o ser humano deve atravessar para aceder a uma existência responsável, autêntica e criadora. $^{20}$ (ELIADE, 1959, p. 270, tradução nossa)

De acordo com Eliade (1959), a morte, ao simbolizar o Caos inicial, conduz o noviço a um outro modo de existência, um renascimento, uma ressurreição simbólica que é apenas acessível àqueles que conheceram a morte e as trevas.

No cenário dos ritos iniciáticos, a "morte" corresponde ao retorno provisório ao "Caos"; ela é a expressão exemplar de um fim de um modo de ser: o da ignorância e da responsabilidade infantil. A morte iniciática torna possível a

20 No original: "Pour revenir aux éléments initiatiques, on les reconnaît encore, à côté d'autres structures de l'expérience religieuse, dans la vie imaginaire et onirique de l'homme moderne. Mais on les reconnait aussi dans certains types d'épreuves réelles qu'il affronte, dans les crises spirituelles, la solitude et le désespoir que tout être humain doit traverser pour accéder à une existence responsable, authentique et créatrice." 


\section{Criaçãa \&}

tábua rasa na qual virão inscrever-se revelações sucessivas, destinadas a formar um homem novo ${ }^{21}$. (ELIADE, 1959, p. 17, tradução nossa)

Esta morte é indispensável ao recomeço da vida espiritual. A passagem do mundo profano ao mundo sagrado apenas é possível através da morte iniciática. O que há de curioso em ambas as obras é que o mundo profano é representado pela Igreja Católica, pelos dogmas cristãos, pela Inquisição, pelo pecado, pelo Inferno e pelo Demo. Após todos os obstáculos ultrapassados, após todas as mortes vividas ou presenciadas, o protagonista irá aceder ao mundo sagrado, sendo este mundo sagrado não a religiosidade ou o mundo cristão, mas sim o acesso à liberdade plena do Homem, o acesso ao conhecimento, ao absoluto.

Nas duas narrativas, as mortes vividas pelos protagonistas vão transformar-se numa unidade maior e que dará sentido à trajetória formativa do herói.

\section{Homens de Deus a caminho da descrença}

A travessia, ao conduzir os protagonistas num caminho de formação e aprendizagem, leva-os a também a enfrentar vários estados como a recusa, a aceitação, o refúgio na religião como única solução possível e o repúdio de Deus como entidade incapaz da salvação.

Os processos de descrença que enfrentam Francisco José e Nsaku Ne Vunda são diferentes, mas complementares.

Em A Rainha Ginga, Francisco José, desde o início da narração, dá a conhecer ao leitor a sua posição em relação à Igreja Católica. O espírito crítico e a lucidez que adquire com o tempo, permitem-lhe comparar as práticas da Igreja com as cerimónias tribais e superstições gentílicas a que assistiu:

Tantos anos decorridos, olhando sobre os meus débeis ombros para o alvoroço do passado, sei não serem tais práticas mais diabólicas do que tantas outras de que eu mesmo fui testemunha no seio da Igreja Católica. Violências, injustiças, infindáveis iniquidades, que a mim se me afiguram ainda mais torpes do que as cometidas pelos ímpios, pois se aqueles ignoram Deus, os cristãos erram em nome Dele. (AGUALUSA, 2014, p. 16)

O leitor sabe qual é o seu posicionamento em relação à religião, uma vez que a narração é feita em analepse. No entanto, num encontro com Domingos Vaz (o qual poderá também ser interpretado como um mentor), quando este lhe diz "O Deus dos Cristãos está muito longe", a reação de Francisco José surpreende-nos: "Ouvindo-o,

21 No original: "Dans le scénario des rites initiatiques, la « mort " correspond au retour provisoire au " Chaos ॥; elle est donc l'expression exemplaire de la fin d'un mode d'être : celui de l'ignorance et de la responsabilité enfantine. La mort initiatique rend possible la tabula rasa sur laquelle viendront s'inscrire les révélations successives, destinées à former un homme nouveau. " 


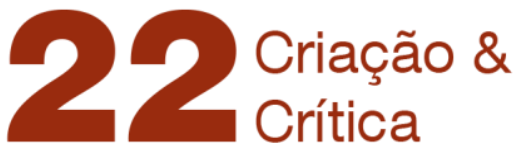

estremeci" (AGUALUSA, 2014, p. 22). Do mesmo modo, quando o personagem aceita estar a serviço da Ginga, trata-se de um passo a mais, inconsciente ou consciente, em relação ao desprendimento da religião católica

Ao ir ter com a Ginga estava na verdade fugindo da Igreja - mas nessa altura ainda não o sabia, ou sabia, mas não ousava enfrentar as minhas mais íntimas dúvidas. Outra coisa não fiz o resto da minha vida, que vai já tão longa e desordenada, senão fugir da Igreja. (AGUALUSA, 2014, p. 26)

O processo de descrença do padre Francisco José no romance A Rainha Ginga é bastante curioso, pois aos poucos ele vai sendo influenciado pela sua vivência em Angola e com Ginga; vai nutrindo sentimentos contraditórios em relação aos portugueses e aos africanos; vai analisando e descrevendo os cultos religiosos africanos e comparando-os aos da Igreja Católica. Declara quase no início da diegese ser um homem livre e não mais um homem da Igreja, mas o seu processo de descrença, que culmina com a recusa a que o chamem padre, apenas acontece perto do final do romance.

Mesmo pondo em causa a existência de Deus, pecando segundo os preceitos e dogmas católicos, Francisco José apenas diz já não ser padre após o auto de fé simbólico realizado em Lisboa (o conhecimento deste fato a posteriori perturba-o) e a sua excomunhão pela Igreja Católica. A expulsão da Igreja acontece não devido à descrença do padre ou aos pecados carnais cometidos com Muxima ou Sula, mas por ter apoiado a causa de Ginga em detrimento da causa portuguesa.

Sentia-me tomado por uma terrível angústia. Custava-me mentir. Custavame ainda mais assumir o papel de traidor. Eu traíra os meus, conquanto nunca os tivesse sentido como meus, senão que com eles partilhava a língua e a fé em Nosso Senhor Jesus Cristo. (AGUALUSA, 2014, p. 72)

Adivinhou a confusão que ia na minha alma, o tormento de me achar tão dividido entre a fé em Cristo e um amor contra Deus e contra a lei, por um lado, e, por outro, entre a bandeira de Portugal e a causa justa, porém inimiga, da rainha Ginga. (AGUALUSA, 2014, p. 81)

Após um sonho, o protagonista tem um momento de lucidez no qual constata ter o seu destino ligado ao de Muxima para sempre. Este momento de lucidez aparece relativamente cedo na narração: é através do amor, ainda não consumado, que o protagonista se liberta (após os dias de clausura e da viagem vivida, mas não narrada).

Acordei alagado em suor e tremendo muito, e subitamente tudo era lúcido e claro como uma tarde de sol. O meu destino estava ligado ao de Muxima, para sempre, para além de existir tempo e o veneno do tempo, e não havia pecado nisso, pois não havia pecado. Já não era mais um servo do Senhor Jesus, era um homem livre. (AGUALUSA, 2014, p. 54) 


\section{Criaçãa \&}

Não é a viagem que o leva à descrença, mas o amor por Muxima. A travessia aqui será de ordem interna, espiritual. O protagonista, após um período de reclusão num espaço confinado, passará do Caos à Ordem, do profano ao sagrado absoluto que será a libertação dos dogmas. Não se tratará apenas de uma simples descrença, mas de uma descoberta do Todo, do universal, o qual começa por si mesmo.

Durante a difícil viagem que os leva de Angola ao Brasil, nas últimas noites da travessia, o bom humor e a boa disposição que tinham reinado a bordo cessaram. Os escravos já não dançavam nem faziam acrobacias. Já não havia alimento e a água escasseava. Neste momento da narração, o leitor depara-se com a frase: "Rezávamos para que o vento nos empurrasse para terra" (AGUALUSA, 2014, p. 155). A curta descrição desta viagem é feita realçando, somente no final da viagem, a escassez de água e de comida. Escravos, marinheiros e tripulantes dormiam, comiam e folgavam juntos. Não existe qualquer descrição de violência, nem de dor ou sofrimento. Apesar de sabermos que o protagonista já não acredita em Deus pois foi referido várias vezes ao longo da narrativa, neste trecho o mesmo refere que rezavam para alcançarem a terra. A crença surge aqui no momento de dificuldade e de sofrimento. Interessa-nos questionarmo-nos se se trata de um retorno à fé ou simplesmente de um hábito católico?

A primeira vez que o protagonista assume publicamente já não ser padre é após a viagem de retorno a Angola. Depois dos meses de clausura no engenho pernambucano, onde foi aprisionado e torturado, e também onde sentiu um sentimento de fraternidade e aconchego com os seus companheiros de viagem Ingo e Rafael, Francisco José encontra Ginga, que estranha não o ver de batina. Este responde-lhe que já não é padre.

Salientamos ainda as considerações que Francisco José tece, já no fim da sua vida, e que correspondem com o auge da sua formação enquanto indivíduo pleno, com uma visão e percepção do Homem e do mundo nítidas e lúcidas

Atente-se no meu caso, que fui um jovem padre e devoto e me acho hoje, à beira da morte, não só afastado de Cristo, mas de qualquer Deus, pois todas as religiões me parecem igualmente danosas, culpadas do muito ódio e das muitas guerras em que a humanidade se destrói. O que é que o jovem padre que desembarcou em África, pela primeira vez, há oitenta anos, diria ao velho, imensamente velho, que eu sou (ou estou) hoje enquanto escrevo estas linhas? Creio que não se reconheceria em mim. (AGUALUSA, 2014, p. 245)

No romance Un océan, deux mers, trois continents, o caminho da descrença é bastante mais sinuoso e menos linear do que em $A$ Rainha Ginga. Na obra de N'Sondé, hesitamos em afirmar que o percurso iniciático de Dom António Manuel culmina na descrença. É certo que uma transformação é operada e que a relação com Deus e com a fé é tumultuosa ao longo da relação, mas a verdadeira descrença que o protagonista irá experienciar é nos homens da religião, na lgreja Católica enquanto instituição e não em Deus propriamente dito. 


\section{Criricãaa \&}

O primeiro momento de dúvida que assola o protagonista é durante a inspeção das escravas que embarcavam antes dos homens. Nsaku Ne Vunda observa, aterrado, testemunhando o medo vivido e o sofrimento anunciado daquelas mulheres:

Com a minha cruz entre as mãos, apenas tinha a minha fé em Nosso Senhor e algumas orações para aliviar a alma daquelas moças. Perguntava-me por que razão o Todo-Poderoso teria escolhido aquele destino para aquelas infelizes, que acabavam de sair da infância, e eu, o seu humilde servo, estava ainda longe de poder mudar o curso da existência delas. ${ }^{22}$ (N'SONDÉ, 2018, p. 69, tradução nossa)

Já embarcados, em alto mar, com uma violência até então nunca sentida, com o sentimento de estar perante o fim da civilização e dos homens, com uma existência atroz e insuportável, Dom António Manuel afirma: "O Criador estava ausente"23 (N'SONDÉ, 2018, p. 100, tradução nossa).

Perante todo o sofrimento do mundo a bordo daquele navio, não havia Deus nem religião capaz de domar os homens. O mundo limitáva-se àquele minúsculo navio no meio do oceano onde não havia leis terrestres nem celestais. Deus estava ausente e o padre impotente perante o horror e o absurdo da crueldade humana. "Onde estavas tu, meu Deus, quando o oceano se fechou sobre mim?"24 (N'SONDÉ, 2018, p. 104, tradução nossa), questiona novamente Nsaku ao longo da narração.

Este questionamento de Deus é consciente no protagonista. Ele sabe que todo o sofrimento que presenciou abalou profundamente a sua fé em Deus.

O herói, afetado por todas as mudanças no seu núcleo de vida recentemente alterado, questiona continuamente Deus e duvida da sua fé. Num certo momento, perante um suicídio coletivo a bordo do navio, ele chega mesmo a questionar a posição da Igreja sobre esta questão, tendo a convicção de que se trata de uma injustiça, na medida em que o calvário já foi vivido na terra.

Assistimos a uma progressiva tomada de consciência, por parte de Dom António, das transformações que ele vive ao longo do seu périplo, permitindo-lhe ir contra as regras e os dogmas da Igreja.

O meu coração tornara-se amargo a Deus e aos meus antepassados. Sentindo o fim tão próximo, despojei-me lentamente de mim, a um passo de atravessar as ruínas do pórtico da morte. Entregava-me sem resistência

22 No original: "Ma croix serrée entre les mains, je n'avais que ma foi en notre Seigneur et quelques prières pour soulager l'âme de ces filles. Je me demandais pourquoi le Tout-Puissant avait choisi ce destin-là pour ces malheureuses à peine sorties de l'enfance et moi, son humble serviteur, j'étais encore loin de pouvoir changer le cours de leurs existences".

23 No original: "Le Créateur s'était absenté".

24 No original: "Où étiez-vous, mon Dieu, quand l'océan se referma sur moi?". 


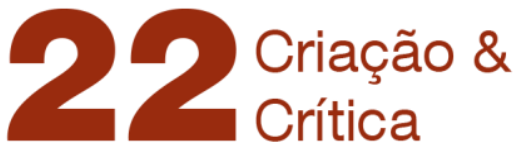

ao destino e não sentia mais nada. Uma estranha transformação se operara em mim. ${ }^{25}$ (N'SONDÉ, 2018, p. 241, tradução nossa)

Assistimos aqui a um reconhecimento da própria transformação que se operou no protagonista. A aprendizagem, que ainda não é consciente, é formativa e vai alterar a visão e a percepção do mundo que o rodeia, neste caso o mundo católico e as tradições ancestrais.

Nestes dois romances de aprendizagem, vemos que a travessia do oceano Atlântico se converte num percurso iniciático (com as características próprias dos ritos de iniciação) e que tanto o trajeto físico como a travessia interior vivida pelos personagens irão influenciar e transformar os protagonistas dos romances estudados.

Vivendo uma ou várias mortes iniciáticas e uma posterior ressurreição simbólica, os dois personagens tecem reflexões e considerações lúcidas que, perante o sofrimento próprio ou alheio, os conduzem a um estado de questionamento que favorece a descrença religiosa e/ou institucional.

Esta travessia atlântica, com o deslocamento de um continente a outro atravessando uma ou várias vezes o mesmo oceano, culminará num processo de reconstrução identitária. $O$ périplo atlântico, a travessia e a viagem não deixarão o Homem indiferente. Todos os horrores vividos, presenciados na primeira pessoa, levarão os nossos protagonistas a um processo de consciência de si mesmos, à consciência plena da existência do Outro.

Também o Oceano, como referente geográfico fluido e catalisador destas transformações, terá um papel fundamental. De acordo com o Chevalier e Gheerbrant, tudo sai do mar e tudo retorna ao mar. Trata-se de um lugar de nascimentos, transformações e de renascimentos. O mar simboliza um estado transitório (CHEVALIER e GHEERBRANT, 1982).

A experiência de formação do ser humano, a transição de um estado a outro acontece, neste espaço, devido às dinâmicas culturais aí existentes e à circulação em torno deste elemento, que levam ao encontro com o Outro e, posteriormente, conduzem o indivíduo a um estado de questionamento e de reflexão. A reconstrução identitária e a consciência humanista, após a morte iniciática simbólica, vivida quer em plena travessia, quer em terra, levarão as personagens a viverem um processo paulatino de questionamento de Deus, da fé, dos dogmas incutidos pela Igreja Católica e aprendidos ao longo da formação religiosa. Tudo isso culminará no questionamento e na recusa dos dogmas em momentos diferentes da diegese, mas nos dois casos este processo corresponde a uma libertação dos personagens e a um acesso a uma verdade única, universal e absoluta, que não é aquela apresentada (ou representada) pela Igreja.

A travessia atlântica está assim imbuída de um simbolismo iniciático que representa não apenas o acesso a uma outra existência, através de uma morte espiritual, como também possibilita a formação do Homem enquanto ser pleno, íntegro e livre.

25 No original: "Mon cœur devint amer à Dieu et aux aïeux. Sentant la fin si proche, je me dépouillais lentement de ma personne, à un pas de traverser les ruines du portique de la mort. Je m'abandonnais sans résistance au destin et ne sentais plus rien. Une étrange transformation s'opéra en moi". 


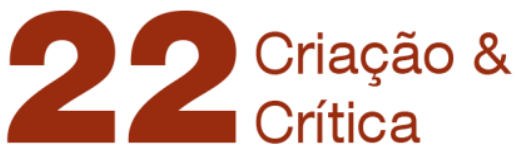

\section{Referências}

AGUALUSA, J. E. A Rainha Ginga E de como os africanos inventaram o mundo. Lisboa: Quetzal Editores, 2014.

CHEVALIER, J.; GHEERBRANT, A. Dictionnaire des symboles: mythes, rêves, coutumes, gestes, formes, figures, couleurs, nombres. Paris: Éditions Robert Laffon, S.A et Éditions Jupiter, 1982.

DEMORAND, N. Premières leçons sur le roman d'apprentissage. Paris: Presses Universitaires de France, 1995.

ELIADE, M. Initiation, rites, sociétés secrètes - Naissances mystiques Essai sur quelques types d'initiation. Paris: Éditions Gallimard, 1959.

LUKACS, G. Le roman historique. Paris: Éditions Payot, 1965.

MENDES, J. P. Considerações sobre Humanismo. HVMANITAS - v. XLVII, 1995. Disponível

em:<https://www.uc.pt/fluc/eclassicos/publicacoes/ficheiros/humanitas47/50.1_Joao_Pedr o_Mendes.pdf>. Acesso em: 7 novembro 2018.

MOURA, J.-M. Les empires et le projet d'une histoire littéraire de l'Atlantique. Les empires de l'Atlantique. Figures de l'autorité impériale dans les lettres d'expression européenne de l'espace atlantique, Bécherel, 2012. p. 11-26.

MOURA, J.-M.; PORRA, V. L'Atlantique littéraire. Perspectives théoriques sur la constitution d'un espace translinguistique. Hildesheim: Georg Olms Verlag AG, 2015.

N'SONDÉ, W. Un océan, deux mers, trois continents. Paris: Actes Sud, 2018.

POTEVIN, M. Parodie et démesure dans la réécriture de l'Histoire transatlantique chez Roberto Bolaño et V. S. Naipaul. In: CLAVARON, Y.; MOURA, J.-M. Les empires de l'Atlantique. Figures de l'autorité impériale dans les lettres d'expression européenne de l'espace atlantique. Bécherel: Éditions Les Perséides, 2012. p. p. 85-97.

PUGA, R. M. O Bildungsroman (romance de formação). Perspectivas. Londres: Institute of Modern Languages Research , 2016.

QUINTALE NETO, F. Para uma interpretação do conceito de Bildungsroman. Pandaemonium Germanicum, № 9, 17 dezembro 2005. p. 185-205.

RENDALL, S.; AL., E. Dictionay of Untranslatables: A Philosophical Lexicon. [S.I.]: Princeton University Press, 2014. Disponível em: <http://www.jstor.org/stable/j.ctt5hhntn>. Acesso em: 05 novembro 2018.

Recebido em: 30/08/2018

Aceito em: 15/11/2018

Referência eletrônica: SILVA, Andreia Joana Oliveira da. A Travessia Atlântica como um Trajeto Iniciático nos Romances de Formação Un Océan, Deux Mers, Trois Continents, de Wilfrid N'sondé, e A Rainha Ginga, de José Eduardo Agualusa. Criação \& Crítica, n. 22, p., dez. 2018. Disponível em: <http://revistas.usp.br/criacaoecritica>. Acesso em: dd $\mathrm{mmm}$. aaaa. 